Article

\title{
Extraction and Optimization of Potato Starch and Its Application as a Stabilizer in Yogurt Manufacturing
}

\author{
Ammar B. Altemimi id \\ Department of Food Science, College of Agriculture, University of Basrah, Basrah 61004, Iraq; \\ ammaragr@siu.edu or ammar.ramddan@uobasrah.edu.iq
}

Received: 30 December 2017; Accepted: 26 January 2018; Published: 29 January 2018

\begin{abstract}
Starch is increasingly used as a functional group in many industrial applications and foods due to its ability to work as a thickener. The experimental values of extracting starch from yellow skin potato indicate the processing conditions at $3000 \mathrm{rpm}$ and $15 \mathrm{~min}$ as optimum for the highest yield of extracted starch. The effect of adding different concentrations of extracted starch under the optimized conditions was studied to determine the acidity, $\mathrm{pH}$, syneresis, microbial counts, and sensory evaluation in stored yogurt manufactured at $5{ }^{\circ} \mathrm{C}$ for 15 days. The results showed that adding sufficient concentrations of starch $(0.75 \%, 1 \%)$ could provide better results in terms of the minimum change in the total acidity, decrease in $\mathrm{pH}$, reduction in syneresis, and preferable results for all sensory parameters. The results revealed that the total bacteria count of all yogurt samples increased throughout the storage time. However, adding different concentrations of optimized extracted starch had a significant effect, decreasing the microbial content compared with the control sample $\left(\mathrm{Y}_{\mathrm{C}}\right)$. In addition, the results indicated that coliform bacteria were not found during the storage time.
\end{abstract}

Keywords: yogurt; syneresis; microbial counts; gelatin; stabilizers; potato starch

\section{Introduction}

Yogurt is a dairy product that has been known and widely consumed for a long time because it is beneficial for nutrition and has significant health effects [1]. Various types of yogurt are available on the market, such as liquid yogurt, sweetened, plain, flavored, frozen, and stirred yogurt. It is thought to prolong human life because of its protein content and minerals, in addition to being a good source of vitamin B [2,3]. Human consumption of yogurt has been linked with health benefits due to improved digestive function and a reduced risk of disease [4,5]. Scientists and researchers also pointed out the possibility of consuming yogurt instead of milk, especially for children and adults who suffer from lactose intolerance, because of its low lactose content [6].

Stabilizers are important ingredients in manufactured dairy products because of their capability to improve viscosity and sensory properties, and inhibit or decrease whey separation during storage, as well as enhance the ratio of total solids in manufactured dairy products [7]. Stabilizers have also been reported to show several secondary functional properties, but we need to assess their impact on physical, chemical, and sensory properties [8]. There are many sources of stabilizers. Some are synthetic (for example Carboxyl Methyl Cellulose); many of them have a plant origin, which is considered the cheapest and includes the most widely used ones such as corn starch, while a few, like gelatin, are of animal origin $[9,10]$. Gelatin is one of the most important stabilizers used in manufactured dairy products because it has a great effectiveness in increasing the viscosity and improving the qualities of dairy products [11]. However, the use of gelatin has decreased in recent years because of the cost as well as an increased demand for Halal and natural stabilizers and growing concern from consumers about using animal sources of gelatin [12]. 
Starch is increasingly used as a functional group either in industrial applications or food due to its ability to work as a thickener [13]. Starch is also widely used in yogurt manufacturing as a thickener to reduce defects, making the body and texture of manufactured yogurt appealing as well as reducing cracks in the surface of the curd milk [14,15]. Therefore, many plants were used to extract starch. For instance, Ammar et al. [16] suggested using Taro (Colocassia esculenta) because it is a good source of starch $(70-80 \%)$, in addition to the ease of digestion and its positive effect on the properties of the final products. Potato is also an important ingredient for nutrition because it is a good source of starch, vitamins $A$ and $C$, and minerals such as iron and potassium, in addition to different ratios of fibers [17].

Ipomoea batatas has been used as a major source of extracting starch in large quantities, especially in developed countries, where potato production accounts for $95 \%$ of total world food production [18]. The major objectives of this research are: (1) to extract and study the effect of extraction parameters $X_{1}$ (centrifugal speed, rpm) ranging from (1000 to 3000) rpm and $X_{2}$ (centrifugal time, min) ranging from (5 to 15) min on the yield of starch from yellow skin potato; (2) to determine the quality of yogurt stabilized with potato starch during storage for 15 days in a refrigerator.

\section{Materials and Methods}

Yellow skin potatoes for extraction of starch were obtained from the local market in Basrah city, Iraq. Fresh cow's milk for making yogurt was obtained from the dairy farm of the College of Agriculture, University of Basrah, Basrah, Iraq. Gelatin and a freeze-dried starter culture of Streptococcus thermophilus and Lactobacillus bulgaricus were provided by the Department of Food Science, College of Agriculture, University of Basrah.

\subsection{Extraction of Starch from Yellow Skin Potato}

Six hundred grams of potatoes were washed thoroughly, peeled, sliced, and chopped into small chunks. The distilled water was added to the chopped potato and the extraction process was carried out through the use of a centrifuge at different speeds $(1000,2000,4000) \mathrm{rpm}$ for different periods of time $(5,10,15 \mathrm{~min})$. Thereafter, the centrifuged samples were filtered using Whatman no. 1 and the supernatant was neglected to obtain wet starch. The wet starch was dried at room temperature for $5 \mathrm{~h}$, then crushed into a fine powder and stored in sealed containers for later use.

\subsection{Preparation of Yogurt}

The raw milk was filtered of impurities using clean gauze. Then, the extracted starch under the optimized condition was added at different concentrations, as shown in Table 1 . Gelatin $(0.6 \%)$ was used as a standard sample to make yogurt. Then, the temperature of milk was gradually increased to $90^{\circ} \mathrm{C}$ for $30 \mathrm{~min}$ with constant stirring to make sure the extracted starch dissolved. Pasteurized cow's milk was rapidly cooled to $43{ }^{\circ} \mathrm{C}$ for the purpose of adding $3 \%(w / v)$ of starter culture and stirring for $4 \mathrm{~min}$. Thereafter, sterilized plastic containers with a tight seal were completely filled with milk and transferred to an incubator, where they were kept at $42^{\circ} \mathrm{C}$ for $4 \mathrm{~h}$ until the completion of coagulation. Manufactured yogurt was stored in a refrigerator at $5^{\circ} \mathrm{C}[19]$.

Table 1. The work plan within the optimized condition.

\begin{tabular}{ccc}
\hline Yogurt Treatment & Extracted Potato Starch \% (v/w) & Gelatin \% (v/w) \\
\hline $\mathrm{Y}_{\mathrm{G}}$ & - & 0.6 \\
$\mathrm{Y}_{\mathrm{C}}$ & 0 & - \\
$\mathrm{Y}_{1}$ & 0.25 & - \\
$\mathrm{Y}_{2}$ & 0.5 & - \\
$\mathrm{Y}_{3}$ & 0.75 & - \\
$\mathrm{Yp}_{4}$ & 1 & - \\
\hline
\end{tabular}

Where $\mathrm{Y}_{\mathrm{G}}=$ standard $\left(0.6 \%\right.$ gelatin), $\mathrm{Yc}_{\mathrm{c}}=$ control yogurt (without any stabilizer), $\mathrm{Yp}_{1}=0.25 \%$ extracted potato starch, $\mathrm{Yp}_{2}=0.5 \%$ extracted potato starch, $\mathrm{Yp}_{3}=0.75 \%$ extracted potato starch, $\mathrm{Yp}_{4}=1 \%$ extracted potato starch. 


\subsection{Analysis of Yogurt}

The $\mathrm{pH}$, acidity, and syneresis of manufactured yogurt were measured in triplicate to avoid error during the 15 -day storage at $5{ }^{\circ} \mathrm{C}$.

\subsection{Acidity of Yogurt}

The acidity value was calculated based on the method described by Onwuka [20]. The acidity value was estimated as the amount of $0.1 \mathrm{~N} \mathrm{NaOH}$ solution $(\mathrm{mL})$ used to neutralize $10 \mathrm{~g}$ of yogurt samples, using phenolphthalein as an indicator to achieve a pink color.

\section{5. $p H$ of Yogurt}

The $\mathrm{pH}$ was measured with an electronic digital-type $\mathrm{pH}$ meter (WTW series $\mathrm{pH}-720$ ). Firstly, the electrodes of $\mathrm{pH}$ meter were adjusted and calibrated at room temperature using buffer solutions of $\mathrm{pH} 4$ and 7. Then, electrodes of $\mathrm{pH}$ meter were immersed in a beaker containing $5 \mathrm{~g}$ of yogurt and readings were recorded directly [21].

\subsection{Syneresis of Yogurt}

The degree of syneresis was determined as free whey according to the method mentioned by Al-Kadamany et al. [22]. Ten-gram samples of manufactured yogurt were weighed and directly placed on a funnel containing Whatman no. 1 filter paper. The syneresis was assessed according to the following equation after $10 \mathrm{~min}$ of drainage under vacuum conditions:

$$
\text { Free whey }(\mathrm{g} / 100 \mathrm{~g})=\left(\mathrm{W}_{\mathrm{b}}-\mathrm{W}_{\mathrm{a}} / \mathrm{W}_{\mathrm{b}}\right) \times 100 \text {, }
$$

where $\mathrm{W}_{\mathrm{b}}$ : weight of yogurt before drainage, $\mathrm{W}_{\mathrm{a}}$ : weight of yogurt after drainage.

\subsection{Microbiological Analysis of Yogurt}

The total bacteria count can be determined by making a serial dilution to 10 of one gram of each sample of yogurt. Thereafter, $0.1 \mathrm{~mL}$ of each sample of yogurt was placed on nutrient agar plates and incubated at $35^{\circ} \mathrm{C}$ for $48 \mathrm{~h}$. The same procedure was used for counting coliform bacteria, except that nutrient agar was replaced with MacConkey agar, and all petri dishes were incubated at $37^{\circ} \mathrm{C}$ [23].

\subsection{Sensory Evaluation}

The overall acceptability of extracted potato starch in yogurt manufacturing was carried out by a panel of 20 trained panelists from the staff of the Food Science Department, College of Agriculture, University of Basrah according to the method described by Sameen et al. [12]. Appearance, body and texture, flavor, and acidity were assessed for sensory evaluation of manufactured yogurt. The sensory evaluation was done on day 1 , day 5 , day 10 , and day 15 of storage.

\subsection{Experimental Design and Data Analysis}

Two independent variables and three coded levels $(-1,0$ and +1$)$ were used as effective factors: $X_{1}$ (centrifugal speed, $\mathrm{rpm}$ ) ranged from (1000 to 3000) rpm and $X_{2}$ (centrifugal time, min) ranged from (5 to 15) $\mathrm{min}$, while the dependent variable (response variable) was the yield of extracted potato starch. The optimal extraction condition was achieved using a central composite design. The following second-order polynomial model was used to describe the relationship between the two independent variables and the response variable:

$$
Y_{i}=b_{0}+b_{1} X_{1}+b_{2} X_{2}+b_{12} X_{1} X_{2}+b_{11} X_{1}{ }^{2}+b_{22} X_{2}{ }^{2},
$$


where $Y_{i}$ is the predicted response; $b_{0}$ is an intercept; $b_{1}$ and $b_{2}$ are the estimated coefficients of centrifugal speed $\left(X_{1}\right)$ and time $\left(X_{2}\right)$, respectively; $b_{11}$ and $b_{22}$ are quadratic effects; and $b_{12}$ is interaction effect of independent variables. The experimental results were analyzed using the statistical software Design Expert 10.6 (State-Ease Inc., Minneapolis, MN, USA).

\section{Results and Discussion}

Table 2 shows the experimental values of extracting starch from yellow skin potatoes, indicating the processing conditions at $3000 \mathrm{rpm}$ and $15 \mathrm{~min}$ as optimum for the highest yield of extracted starch. From the analysis of variance shown in Table 3, the model was highly significant $(p<0.05)$, which indicated that the models used to fit response variables were sufficient to display the relationship between the yield of starch and the independent variables. The "Lack of Fit F-value" of 2.06 implies the lack of fit is not significant relative to the pure error. There is a $24.32 \%$ chance that a "Lack of Fit $F$-value" this large could occur due to noise. Non-significant lack of fit is recommended for an adequate model. Both linear and square of $X_{1}$ (centrifugal speed, rpm) also showed a $p$-value lower than 0.05 . Furthermore, the linear and square of $X_{2}$ (centrifugal time, min) also showed a $p$-value lower than 0.05 . The interaction between $X_{1}$ (centrifugal speed, rpm) and $X_{2}$ (centrifugal time, min) gave $p<0.05$, which is considered significant. The $R^{2}$ of the models for potato starch yield (\%) was 0.946 .

Table 2. The experimental values using central composite design.

\begin{tabular}{cccc}
\hline Run & $\mathbf{X}_{\mathbf{1}}(\mathbf{r p m})$ & $\left.\mathbf{X}_{\mathbf{2}} \mathbf{( M i n}\right)$ & Potato Starch Yield \% \\
\hline 1 & 3000 & 10 & 11 \\
2 & 1000 & 15 & 8 \\
3 & 2000 & 5 & 8 \\
4 & 1000 & 10 & 7.5 \\
5 & 3000 & 5 & 9.5 \\
6 & 3000 & 15 & 16.5 \\
7 & 2000 & 15 & 10 \\
8 & 1000 & 5 & 7 \\
9 & 1000 & 10 & 8 \\
10 & 2000 & 5 & 7.5 \\
11 & 2000 & 15 & 10 \\
12 & 3000 & 10 & 13 \\
\hline
\end{tabular}

$\mathrm{X}_{1}$ : centrifugal speed; $\mathrm{X}_{2}$ : centrifugal time.

Table 3. The analysis of variance of the fitted quadratic model for potato starch yield (\%).

\begin{tabular}{cccccc}
\hline Source & Degree of Freedom & Sum of Square & Mean Square & $\boldsymbol{F}$-Value & $\boldsymbol{p}$-Value \\
\hline Model & 5 & 80.10 & 16.02 & 21.07 & 0.001 \\
$\mathrm{X}_{1}$ & 1 & 47.53 & 47.53 & 62.51 & 0.0002 \\
$\mathrm{X}_{2}$ & 1 & 19.53 & 19.53 & 25.68 & 0.0023 \\
$\mathrm{X}_{1} \mathrm{X}_{2}$ & 1 & 9 & 9 & 11.84 & 0.013 \\
$\mathrm{X}_{1}{ }^{2}$ & 1 & 3.78 & 3.78 & 4.97 & 0.067 \\
$\mathrm{X}_{2}{ }^{2}$ & 1 & 0.28 & 0.28 & 0.37 & 0.565 \\
Lack of fit & 2 & 2.31 & 1.16 & 2.06 & 0.2432 \\
\hline
\end{tabular}

Three-dimensional (3D) surface plots were assigned in order to study and determine the optimum conditions for independent and dependent variables [24]. The equation in terms of coded factors can be used to make predictions about the response for given levels of each factor. By default, the high levels of the factors are coded as +1 and the low levels of the factors are coded as -1 . The coded equation is useful for identifying the relative impact of the factors by comparing the factor coefficients. The quadratic polynomial model of coded factors is shown below:

$$
\text { Potato Starch Yield } \%=+8.50+2.44 \times \mathrm{X}_{1}+1.56 \times \mathrm{X}_{2}+1.50 \times \mathrm{X}_{1} \mathrm{X}_{2}+1.38 \times \mathrm{X}_{1}^{2}+0.38 \times \mathrm{X}_{2}^{2} \text {. }
$$


As shown in Figure 1, the effect of the variables and their interaction on predicted potato starch yield (\%) was investigated. It showed that as $\mathrm{X}_{1}$ (centrifugal speed) and $\mathrm{X}_{2}$ (centrifugal time) increased, the potato starch yield increased. The optimum centrifugal speed and centrifugal time for maximum potato starch yield were $3000 \mathrm{rpm}$ and $15 \mathrm{~min}$, respectively.

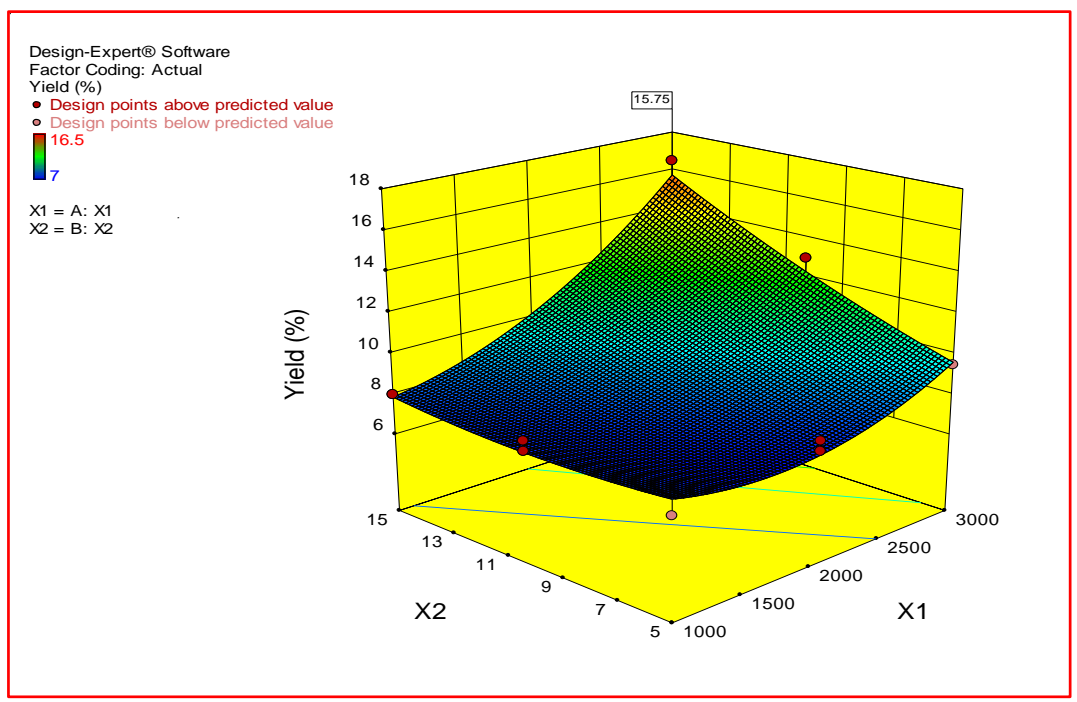

Figure 1. Response surface plot showing the effect of centrifugal speed and centrifugal time on the potato starch yield (\%).

\subsection{Total Acidity in Yogurt Samples}

Table 4 shows the effect of adding the extracted starch from the potatoes under the optimized condition on the total acidity in yogurt stored at $5{ }^{\circ} \mathrm{C}$ for 15 days. The results of the statistical analysis showed that $\mathrm{Yp}_{1}$ and $\mathrm{Yp}_{2}$ exhibited a maximum change in total acidity over storage and were significantly $(p<0.05)$ higher than $\mathrm{Y}_{\mathrm{G}}, \mathrm{Yp}_{3}$, and $\mathrm{Yp}_{4}$, which was not significant $(p>0.05)$ compared to $\mathrm{Y}_{\mathrm{C}}$. The mean values of total acidity were $1.35 \pm 0.56,1.33 \pm 0.56$, and $1.4175 \pm 0.54$ for $\mathrm{Yp}_{1}, \mathrm{Yp}_{2}$, and $Y_{C}$, respectively. This result was in agreement with those of Andic et al. [25] and Anwer et al. [26], who reported a significant relationship between the gradual increase in acidity of yogurt during the storage and the amount of lactic acid produced.

In spite of $\mathrm{Yp}_{3}$ and $\mathrm{Yp}_{4}$ showing a slight increase in the total acidity of manufactured yogurt during storage at $5{ }^{\circ} \mathrm{C}$ for 15 days, the statistical analysis showed that there were no significant differences $(p>0.05)$ between $\mathrm{Yp}_{3}, \mathrm{Yp}_{4}$, and $\mathrm{Y}_{\mathrm{G}}$. This obtained result was in agreement with Kumar and Mishra [27], who found that adding sufficient concentrations of starch could effectively reduce the amount of water, thus making it difficult for bacteria to metabolize lactose sugar and thereby reducing the amount of lactic acid produced.

Table 4. Mean values of total acidity in yogurt manufacturing at $5^{\circ} \mathrm{C}$ for 15 days.

\begin{tabular}{ccccccc}
\hline \multirow{2}{*}{ Storage Period (Days) } & \multicolumn{7}{c}{ Yogurt Treatments ${ }^{*}$} \\
\cline { 2 - 7 } & $\mathbf{Y}_{\mathbf{C}}$ & $\mathbf{Y p}_{\mathbf{1}}$ & $\mathbf{Y p}_{\mathbf{2}}$ & $\mathbf{Y p}_{\mathbf{3}}$ & $\mathbf{Y p}_{\mathbf{4}}$ & $\mathrm{Y}_{\mathbf{G}}$ \\
\hline 1 & 0.75 & 0.75 & 0.74 & 0.49 & 0.53 & 0.55 \\
5 & 1.22 & 0.98 & 0.95 & 0.42 & 0.44 & 0.41 \\
10 & 1.75 & 1.78 & 1.75 & 0.51 & 0.52 & 0.48 \\
15 & 1.95 & 1.89 & 1.88 & 0.61 & 0.59 & 0.53 \\
Means & $1.41 \pm 0.54^{\mathrm{a}}$ & $1.35 \pm 0.56^{\mathrm{a}}$ & $1.33 \pm 0.56^{\mathrm{a}}$ & $0.50 \pm 0.07^{\mathrm{b}}$ & $0.52 \pm 0.06^{\mathrm{b}}$ & $0.49 \pm 0.06^{\mathrm{b}}$ \\
\hline
\end{tabular}

${ }^{*}$ Means with the same superscript letter are not significantly different. 


\section{2. $p H$ of Yogurt Samples}

The results in Table 5 show that adding the starch extracted from yellow potato had a significant effect on the mean value of $\mathrm{pH}$ of yogurt samples. The statistical analysis implied that $\mathrm{Yp}_{1}$ and $\mathrm{Yp}_{2}$ presented the maximum decrease in $\mathrm{pH}$ values and were significantly $(p<0.05)$ less than $\mathrm{Y}_{\mathrm{G}}, \mathrm{Yp}_{3}$, and $\mathrm{Y}_{4}$, which was not significant $(p>0.05)$ compared to $\mathrm{Y}_{\mathrm{C}}$. The mean values of total acidity were $4.16 \pm 0.45,4.205 \pm 0.39$, and $4.10 \pm 0.47$ for $\mathrm{Yp}_{1}, \mathrm{Yp}_{2}$, and $\mathrm{Y}_{\mathrm{C}}$, respectively. These findings were similar to those reported by Seelee et al. [28] and Hassan et al. [29], who declared that the $\mathrm{pH}$ value of yogurt decreased mainly because of the lactic acid produced during storage.

Furthermore, the results revealed that $\mathrm{Yp}_{3}$ and $\mathrm{Yp}_{4}$ displayed a negligible decrease in the $\mathrm{pH}$ of manufactured yogurt during storage at $5{ }^{\circ} \mathrm{C}$ for 15 days. The $\mathrm{Yp}_{3}$ and $\mathrm{Yp}_{4}$ treatments had more capability to resist $\mathrm{pH}$ changes due to their ability to prevent lactose conversion [30]. The statistical analysis showed that there was no significant difference $(p>0.05)$ between $\mathrm{Yp}_{3}, \mathrm{Yp}_{4}$, and $\mathrm{Y}_{\mathrm{G}}$.

Table 5. Mean values of $\mathrm{pH}$ in yogurt manufacturing at $5{ }^{\circ} \mathrm{C}$ for 15 days.

\begin{tabular}{ccccccc}
\hline \multirow{2}{*}{ Storage Period (Days) } & \multicolumn{7}{c}{ Yogurt Treatments } \\
\cline { 2 - 7 } & $\mathbf{Y}_{\mathbf{C}}$ & $\mathbf{Y p}_{\mathbf{1}}$ & $\mathbf{Y p}_{\mathbf{2}}$ & $\mathbf{Y p}_{\mathbf{3}}$ & $\mathbf{Y p}_{\mathbf{4}}$ & $\mathbf{Y}_{\mathbf{G}}$ \\
\hline 1 & 4.74 & 4.75 & 4.71 & 4.75 & 4.74 & 4.74 \\
5 & 4.16 & 4.21 & 4.25 & 4.73 & 4.75 & 4.72 \\
10 & 3.89 & 4.03 & 4.11 & 4.69 & 4.72 & 4.70 \\
15 & 3.64 & 3.67 & 3.75 & 4.61 & 4.63 & 4.59 \\
Means & $4.10 \pm 0.47^{\mathrm{a}}$ & $4.16 \pm 0.45^{\mathrm{a}}$ & $4.20 \pm 0.39^{\mathrm{a}}$ & $4.69 \pm 0.06^{\mathrm{b}}$ & $4.71 \pm 0.05^{\mathrm{b}}$ & $4.68 \pm 0.06^{\mathrm{b}}$ \\
\hline
\end{tabular}

${ }^{*}$ Means with the same superscript letter are not significantly different.

\subsection{Syneresis of Yogurt Samples}

As shown in Table 6, adding different concentrations of extracted starch had highly significant results, decreasing syneresis in manufacturing yogurt during storage at $5{ }^{\circ} \mathrm{C}$ for 15 days. This study indicated that $\mathrm{Yp}_{1}$ and $\mathrm{Yp}_{2}$ exhibited the minimum reduction in syneresis with the passage of time and were significantly $(p<0.05)$ higher than $\mathrm{Y}_{\mathrm{G}}, \mathrm{Yp}_{3}$, and $\mathrm{Yp}_{4}$, which was not significant $(p>0.05)$ compared to $\mathrm{Y}_{\mathrm{C}}$. The mean values of syneresis were $4.32 \pm 1.40,4.38 \pm 1.39$, and $4.45 \pm 1.39$ for $\mathrm{Yp}_{1}$, $\mathrm{Yp}_{2}$, and $\mathrm{Y}_{\mathrm{C}}$, respectively. This result was in accordance with Isleten et al. [31] and Guven et al. [32], who observed that the lowest values of syneresis were obtained during storage compared to the first day of production.

In contrast, both $\mathrm{Yp}_{3}$ and $\mathrm{Yp}_{4}$ treatments displayed preferable results in terms of the reduction in syneresis values during storage at $5{ }^{\circ} \mathrm{C}$ for 15 days. This significant reduction can be ascribed to the ability of a high concentration of starch to increase the concentration of an adsorbing polymer. Previous results of Hasan et al. [33] were in agreement with this present investigation. Moreover, the statistical analysis emphasized that there were no significant differences $(p>0.05)$ between $\mathrm{Yp}_{3}, \mathrm{Yp}_{4}$, and $Y_{G}$.

Table 6. Mean values of syneresis (g/100 g) in yogurt manufacturing.

\begin{tabular}{ccccccc}
\hline \multirow{2}{*}{ Storage Period (Days) } & \multicolumn{7}{c}{ Yogurt Treatments } \\
\cline { 2 - 7 } & $\mathbf{Y}_{\mathbf{C}}$ & $\mathbf{Y p}_{\mathbf{1}}$ & $\mathbf{Y p}_{\mathbf{2}}$ & $\mathbf{Y p}_{\mathbf{3}}$ & $\mathbf{Y p}_{\mathbf{4}}$ & $\mathbf{Y}_{\mathbf{G}}$ \\
\hline 1 & 6.15 & 5.98 & 6.08 & 2.21 & 2.19 & 2.18 \\
5 & 4.85 & 4.91 & 4.81 & 2.15 & 2.01 & 2.07 \\
10 & 3.92 & 3.65 & 3.83 & 1.87 & 1.86 & 1.91 \\
15 & 2.88 & 2.77 & 2.81 & 1.79 & 1.77 & 1.75 \\
Means & $4.45 \pm 1.39^{\mathrm{a}}$ & $4.32 \pm 1.40^{\mathrm{a}}$ & $4.38 \pm 1.39^{\mathrm{a}}$ & $2.0 \pm 0.20^{\mathrm{b}}$ & $1.95 \pm 0.18^{\mathrm{b}}$ & $1.97 \pm 0.18^{\mathrm{b}}$ \\
\hline
\end{tabular}

${ }^{*}$ Means with the same superscript letter are not significantly different. 


\subsection{Microbiological Analysis of Yogurt}

The data regarding microbial population changes of all yogurt samples are given in Figure 2. The results revealed that the total bacteria count in all yogurt samples increased throughout the storage time. Adding different concentrations of optimized extracted starch had a significant effect, decreasing the microbial content compared with the control sample $\left(\mathrm{Y}_{\mathrm{C}}\right)$. This study indicated that $\mathrm{Yp}_{1}$ and $\mathrm{Yp}_{2}$ exhibited the minimum reduction in microbial content with the passage of time and were significantly $(p<0.05)$ higher than $\mathrm{Y}_{\mathrm{G}}, \mathrm{Yp}_{3}$, and $\mathrm{Yp}_{4}$, which was not significant $(p>0.05)$ compared to $\mathrm{Y}_{\mathrm{C}}$. The mean values of the total bacteria count $(\log 10 \mathrm{CFU} / \mathrm{mL})$ during storage at $5{ }^{\circ} \mathrm{C}$ for 15 days were $4.5 \pm 0.23$, $4.6 \pm 0.11$, and $4.8 \pm 0.18$ for $\mathrm{Yp}_{1}, \mathrm{Yp}_{2}$, and $\mathrm{Y}_{\mathrm{C}}$, respectively. However, both $\mathrm{Yp}_{3}$ and $\mathrm{Yp}_{4}$ treatment displayed preferable results in terms of the reduction in microbial content during storage at $5{ }^{\circ} \mathrm{C}$ for 15 days. Moreover, the statistical analysis emphasized that there were no significant differences $(p>0.05)$ between $\mathrm{Yp}_{3}, \mathrm{Yp}_{4}$, and $\mathrm{Y}_{\mathrm{G}}$. This present investigation was not in agreement with previous results of Hasan et al. [33] and Dave et al. [34], who confirmed that there were no significant effects due to different concentrations of stabilizers.

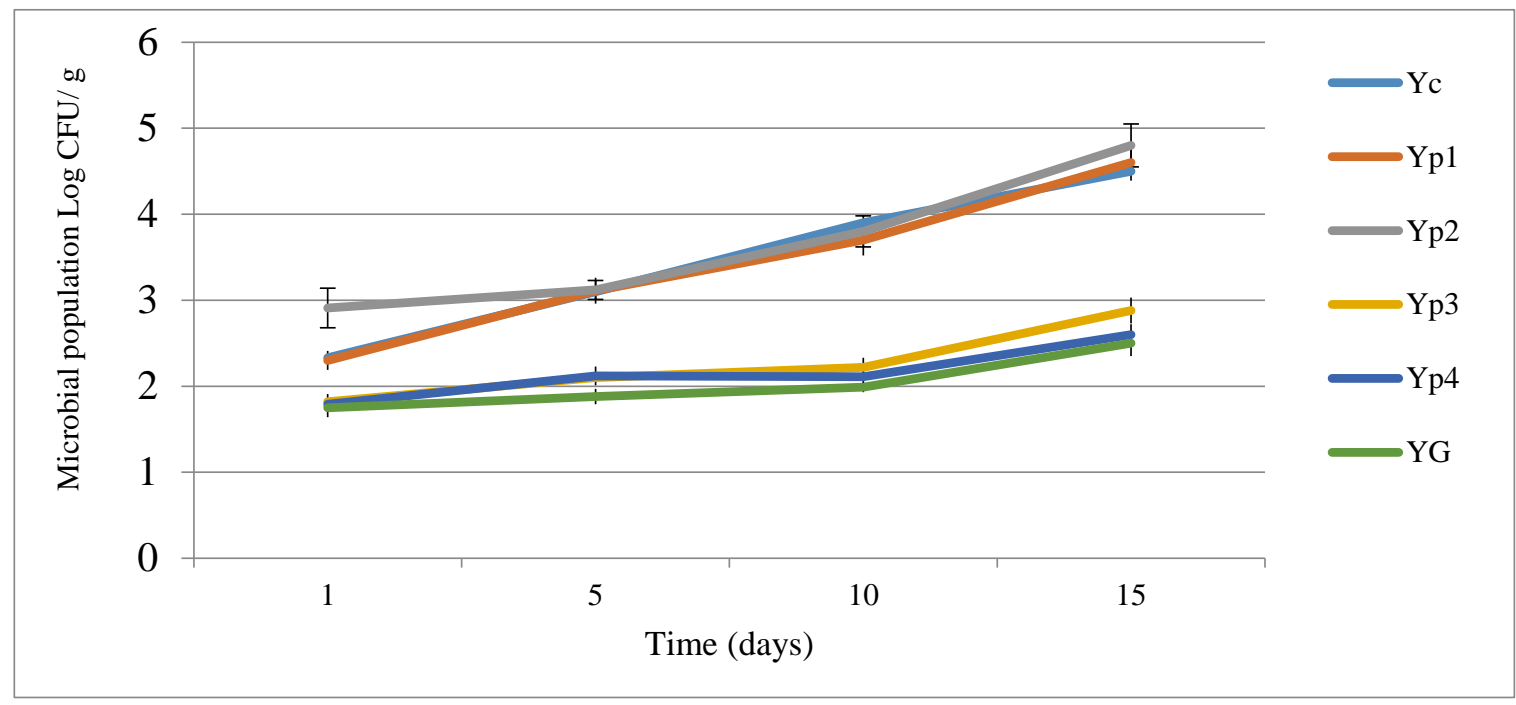

Figure 2. Effect of adding optimized extracted starch on the microbial population of yogurt during storage.

In addition, the results also indicated that coliform bacteria were not found during storage. This result was in accordance with Hasan et al. [33] and Ganesh [35], who confirmed the absence of coliform bacteria because of good storage requirements and avoiding contamination.

\subsection{Sensory Evaluation}

The results in the sensory investigation included appearance, texture, flavor, and acidity, as shown in Figures 3-6. The statistical analysis emphasized that there was no significant difference $(p>0.05)$ between $\mathrm{Yp}_{3}, \mathrm{Yp}_{4}$, and $\mathrm{Y}_{\mathrm{G}}$ for all sensory parameters. This study also indicated that $\mathrm{Yp}_{1}$ and $\mathrm{Yp}_{2}$ had the lowest scores in terms of all sensory parameters with the passage of time and were significantly $(p<0.05)$ lower than $\mathrm{Y}_{\mathrm{G}}, \mathrm{Yp}_{3}$, and $\mathrm{Yp}_{4}$; however, it was not significant $(p>0.05)$ compared to $\mathrm{Y}_{\mathrm{C}}$. This finding was similar to those reported by Malik et al. [7], who confirmed that yogurt samples remained satisfactory during storage at $5{ }^{\circ} \mathrm{C}$ for 15 days for all sensory parameters due to the different concentration of starch extracted from Trapa bispinosa. In contrast, this present study was not in agreement with Sameen et al. [12], who said that there was no statistical difference between adding a different concentration of starch in manufacturing yogurt and the control sample for all sensory parameters. 


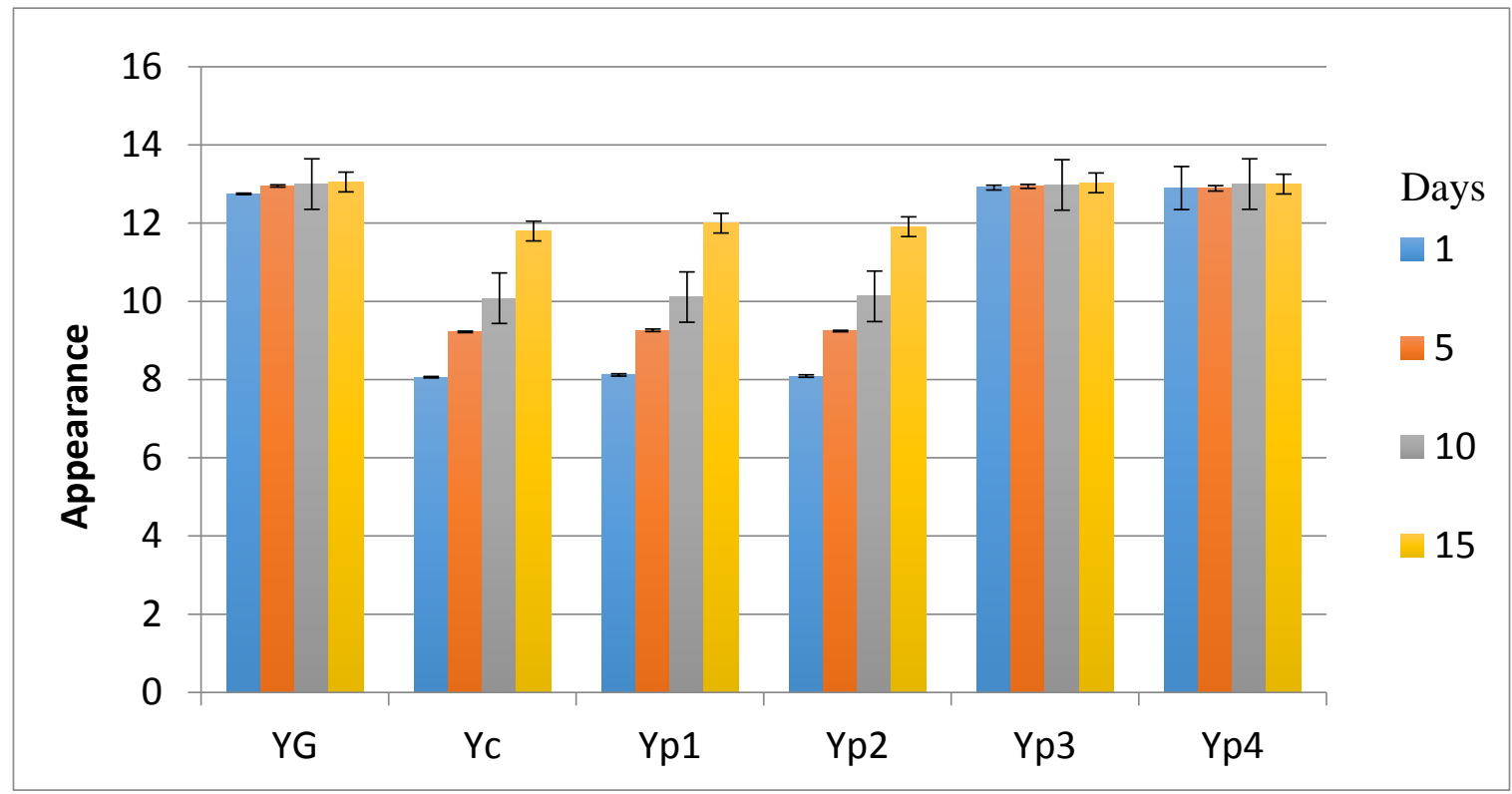

Figure 3. Mean values of yogurt's appearance during storage.

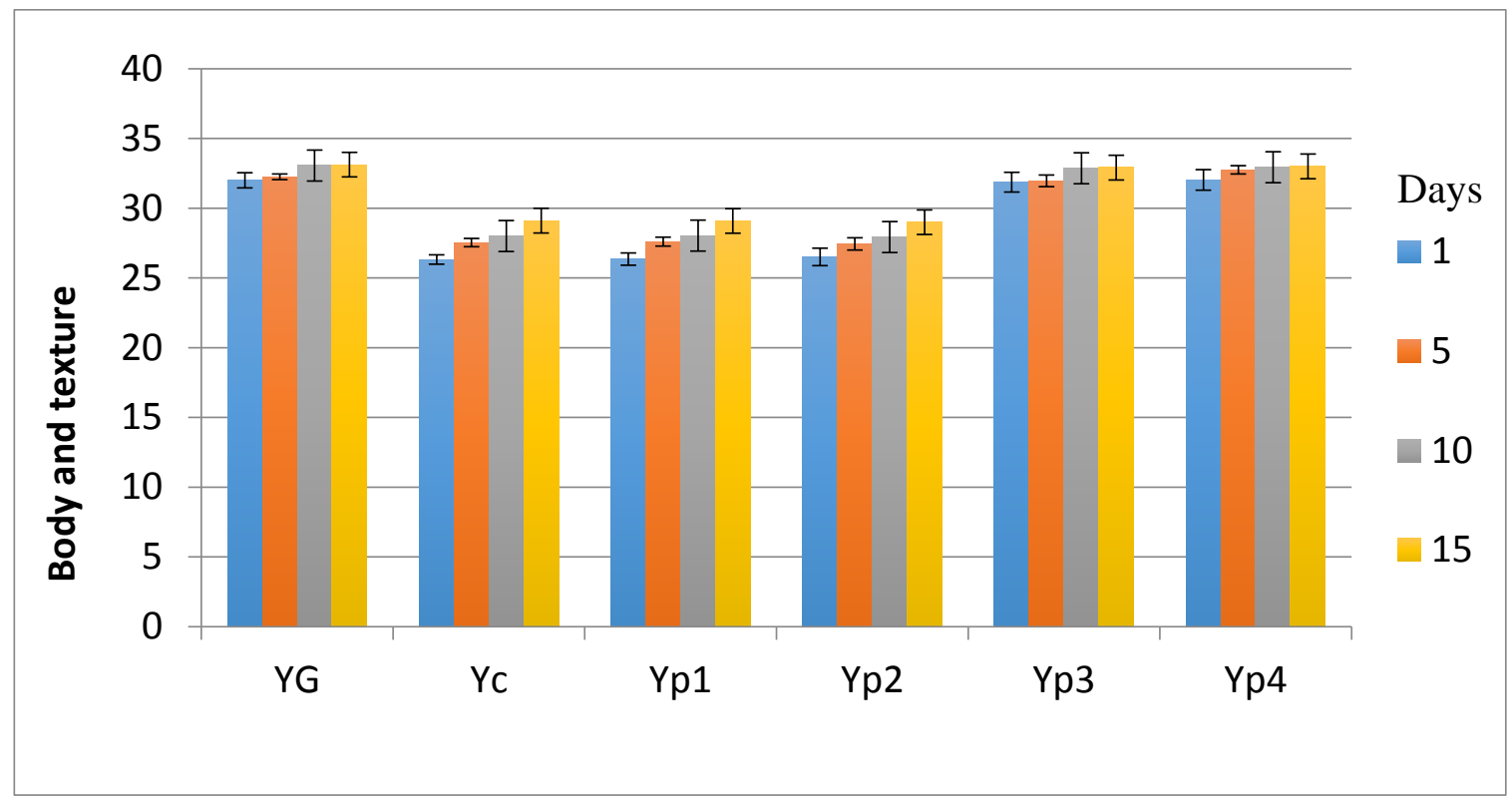

Figure 4. Mean values of yogurt's body and texture during storage. 


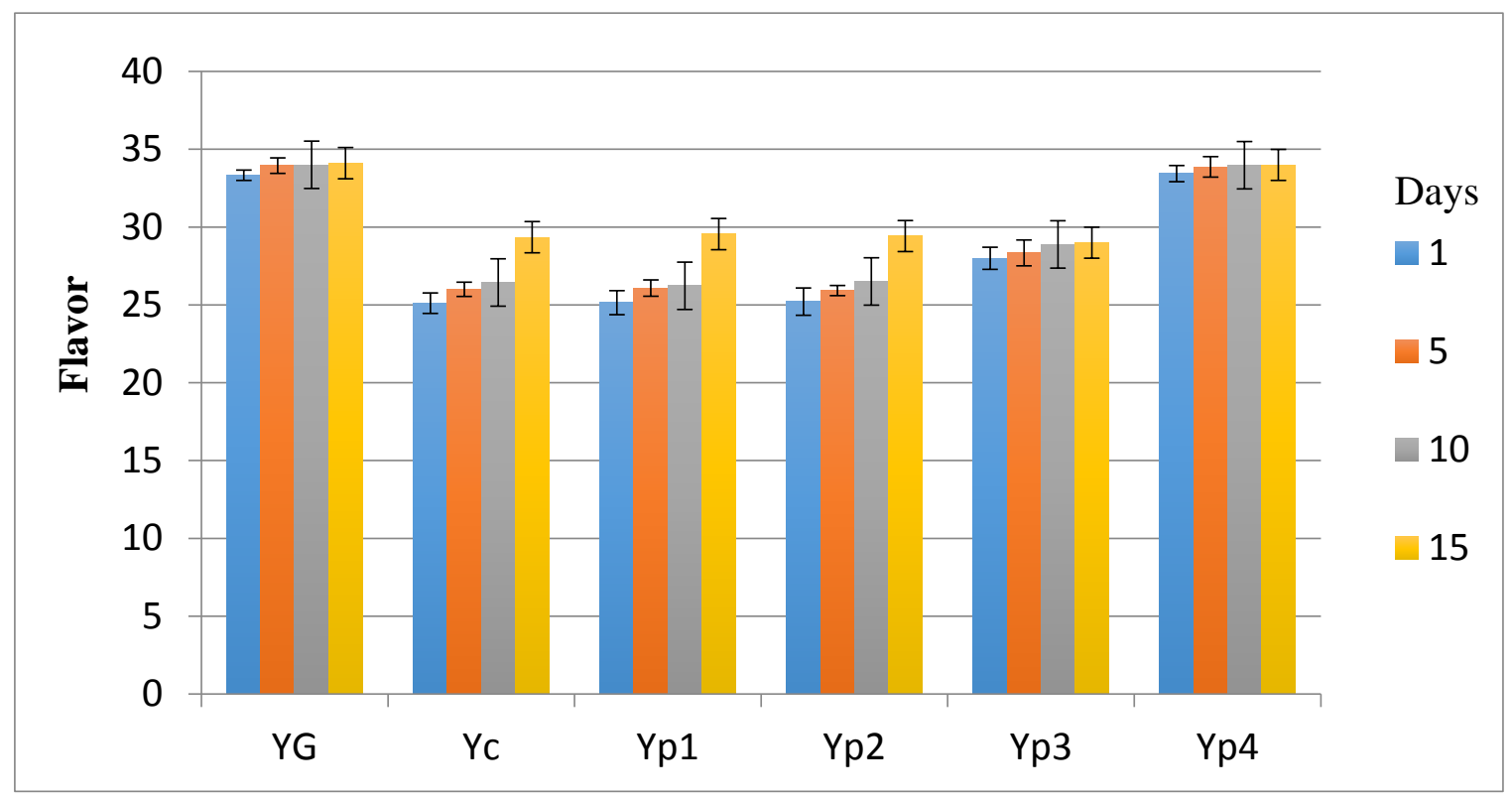

Figure 5. Mean values of yogurt's flavor during storage.

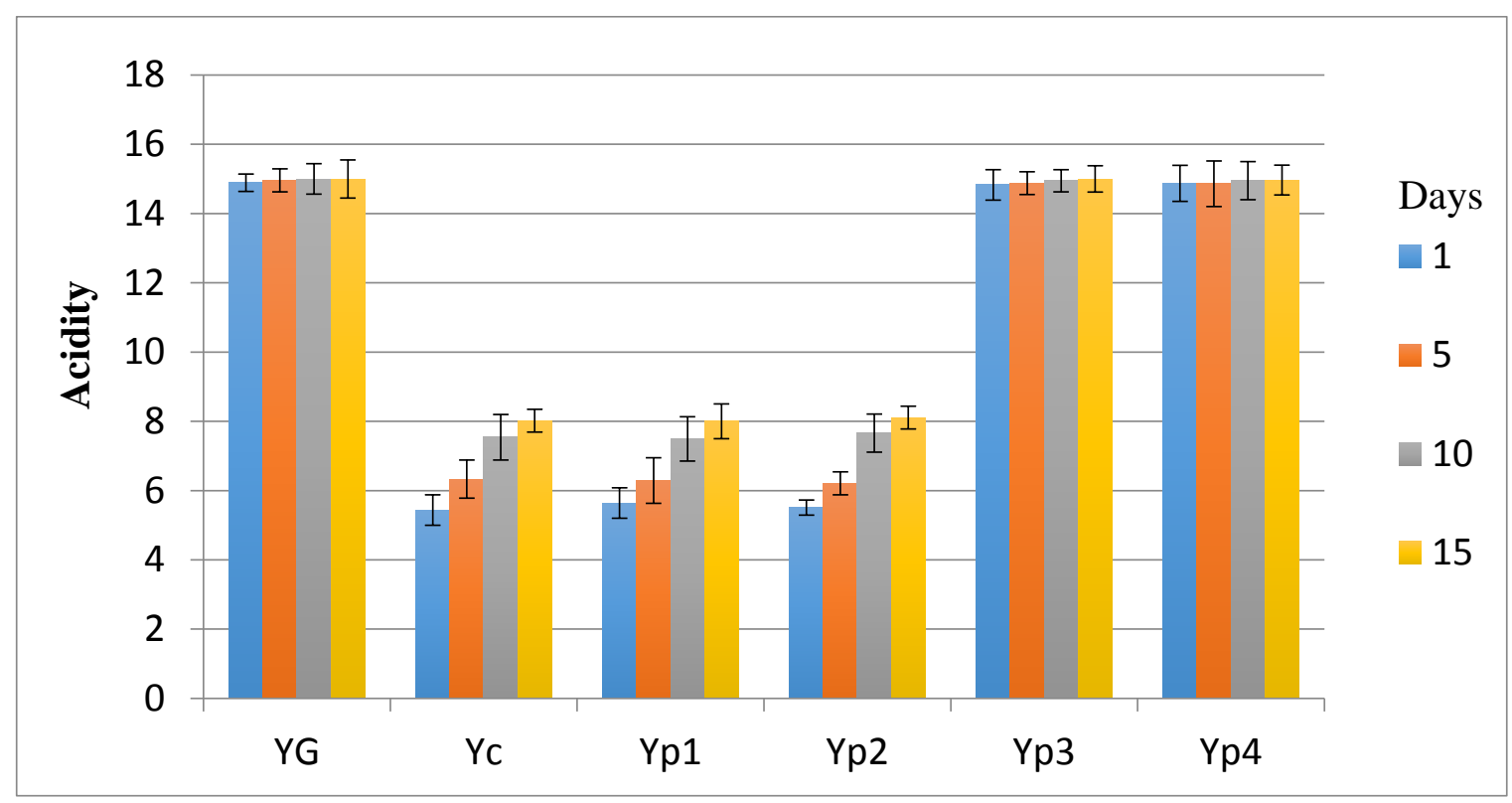

Figure 6. Mean values of yogurt's acidity during storage.

\section{Conclusions}

Stabilizers are important ingredients in manufactured dairy products because of their ability to improve viscosity and sensory properties, and to decrease whey separation during storage. The results showed that adding sufficient concentrations of extracted starch $(0.75 \%, 1 \%)$ gave better results for the total acidity, $\mathrm{pH}$, syneresis, and sensory evaluation. Both $\mathrm{Yp}_{3}$ and $\mathrm{Yp}_{4}$ treatments displayed preferable results in terms of reduction in microbial content during storage at $5{ }^{\circ} \mathrm{C}$ for 15 days. Furthermore, yogurt bacterial counts were also significantly reduced using different concentrations of extracted starch throughout storage. 
Acknowledgments: The author is very much grateful to the food science department, college of Agriculture, University of Basrah for providing equipments and facilities.

Author Contributions: AA, designed, carried out, wrote-up the research and proofread the article.

Conflicts of Interest: The author declares no conflict of interest.

\section{References}

1. Gawai, K.M.; Mudgal, S.P.; Prajapati, J.B. Stabilizers, Colorants, and Exopolysaccharides in Yogurt. In Yogurt in Health and Disease Prevention; Academic Press: London, UK, 2017; p. 49.

2. El-Sayed, E.M.; Abd El-Gawad, I.A.; Murad, H.A.; Salah, S.H. Utilization of laboratory produced xanthan gum in the manufacture of yoghurt and soy yogurt. Eur. Food Res. Technol. 2002, 215, 298-304.

3. Uba, A.; Izuagie, T.; Hassan, L.G.; Achor, M.; Sahabi, D.M. Physicochemical Properties of Starch Isolated from Seeds of Chrysophyllum albidum. Int. J. Chem. Sci. 2011, 4, 264-270.

4. Heyman, M. Effect of lactic acid bacteria on diarrheal diseases. J. Am. Coll. Nutr. 2000, 19, 137S-146S. [CrossRef] [PubMed]

5. Chandan, R.C. An Overview of Yogurt Production and Composition. In Yogurt in Health and Disease Prevention; Academic Press: London, UK, 2017; p. 31.

6. Kolars, J.C. Yoghurt-An auto digesting source of lactose. N. Engl. J. Med. 1984, 310, 1-3. [CrossRef] [PubMed]

7. Malik, A.H.; Anjum, F.M.; Sameen, A.; Khan, M.I.; Sohaib, M. Extraction of starch from Water Chestnut (Trapa bispinosa Roxb) and its application in yoghurt as a stabilizer. Pak. J. Food Sci. 2012, 22, 209-218.

8. Imeson, A. Thickening and Gelling Agents for Foods, 2nd ed.; Aspen Publ. Inc.: Gaithersburg, MD, USA, 1999.

9. Alakali, J.S.; Okonkwo, T.M.; Iordye, E.M. Effect of stabilizers on the physico-chemical and sensory attributes of thermized yoghurt. Afr. J. Biotechnol. 2008, 7, 158-163.

10. Pang, Z.; Deeth, H.; Yang, H.; Prakash, S.; Bansal, N. Evaluation of tilapia skin gelatin as a mammalian gelatin replacer in acid milk gels and low-fat stirred yogurt. J. Dairy Sci. 2017, 100, 3436-3447. [CrossRef] [PubMed]

11. Shi, J.; Han, Y.P.; Zhao, X.H. Quality attributes of set-style skimmed yoghurt affected by the addition of a cross-linked bovine gelatin. CyTA-J. Food 2017, 15, 320-325. [CrossRef]

12. Sameen, A.; Sattar, M.U.; Javid, A.; Ayub, A.; Khan, M.I. Quality evaluation of yoghurt stabilized with sweet potato (Ipomoea batatas) and taro (Colocassia esculenta) starch. Int. J. Food Allied Sci. 2016, 2, 23-29. [CrossRef]

13. Sameen, A.; Manzoor, M.F.; Huma, N.; Sahar, A.; Sattar, U. Quality evaluation of ice cream prepared with Sagudana (Meteroxylon sagu) and Sweet Potato (Ipomoea batatas) starch as stabilizing agent. Pak. J. Food Sci. 2017, 27, 1-6.

14. Kategunya, R.; Sanguansri, C. Physico-chemical properties of jackfruit seed starch (Artocarpus heterophyllus) and its application as a thickener and stabilizer in chilli sauce. LWT-Food Sci. Technol. 2011, 44, 1309-1313.

15. Januário, J.G.B.; da Silva, I.C.F.; de Oliveira, A.S.; de Oliveira, J.F.; Dionísio, J.N.; Klososki, S.J.; Pimentel, T.C. Probiotic yoghurt flavored with organic beet with carrot, cassava, sweet potato or corn juice: Physicochemical and texture evaluation, probiotic viability and acceptance. Int. Food Res. J. 2017, 24, 359-366.

16. Ammar, M.S.; Hegazy, A.E.; Bedeir, S.H. Using of taro flour as partial substitute of wheat flour in bread making. World J. Dairy Food Sci. 2009, 4, 94-99.

17. Khan, K.; Rehman, S.; Khan, M.A.; Anwar, F.; Bhadar, S. Physical and chemical quality appraisal of commercial yoghurt brands sold at Lahore. ARPN J. Agric. Biol. Sci. 2008, 3, 14-20.

18. Ikenebomeh, M.J.; Omogbai, B.A. Chemical analysis and sensory investigation of soymilk yoghurts. Nigerian J. Microbiol. 2000, 14, 85-93.

19. Tamime, A.Y.; Robinson, R.K. Yoghurt Science and Technology; Woodhead Publishing: Cambridge, UK, 1985.

20. Onwuka, G.I. Food Analysis and Instrumentation: Theory and Practice; Naphthali Publishers Ltd.: Lagos, Nigeria; Pergamon Press: Oxford, UK, 2005; pp. 76-82.

21. Olugbuyiro, J.A.; Oseh, J.A. Physico-chemical and sensory evaluation of market yoghurt in Nigeria. Pak. J. Nutr. 2011, 10, 914-918.

22. Al-Kadamany, E.; Khattar, M.; Haddad, T.; Toufeili, I. Estimation of shelf life of concentrated yoghurt by monitoring selected microbiological and physiological changes during storage. LWT-Food Sci. Technol. 2003, 36, 407-414. [CrossRef] 
23. Okoye, J.I.; Animalu, I.L. Evaluation of physico-chemical and microbiological properties of stirred yoghurt stabilized with sweet potato (Ipomoea batatas) starch. Cont. J. Microbiol. 2009, 3, 27-30.

24. Altemimi, A.; Watson, D.G.; Kinsel, M.; Lightfoot, D.A. Simultaneous extraction, optimization, and analysis of flavonoids and polyphenols from peach and pumpkin extracts using a TLC-densitometric method. Chem. Cent. J. 2015, 9, 39. [CrossRef] [PubMed]

25. Andic, S.; Boran, G.; Tuncturk, Y. Effects of carboxyl methyl cellulose and edible cow gelatin on physico-chemical, textural and sensory properties of yoghurt. Int. J. Agric. Biol. 2013, 15, 245-251.

26. Anwer, M.; Ahmad, S.; Sameen, A.; Ahmed, S. Effect of different heating temperatures on the rheological properties of lactic gel made from buffalo milk. J. Food Chem. Nutr. 2013, 1, 33-41.

27. Kumar, P.; Mishra, H. Mango soy fortified set yoghurt: Effect of stabilizer addition on physicochemical, sensory and textural properties. Food Chem. 2004, 87, 501-507. [CrossRef]

28. Seelee, W.; Tungjaroenchai, W.; Natvaratat, M. Development of low fat set type probiotic yoghurt from goat milk. Asian J. Food Agro-Ind. 2009, 2, 771-779.

29. Hassan, F.A.; Helmy, W.A.; Enab, A.K. Utilization of some local polysaccharide in manufacture of yoghurt. Egypt. J. Dairy Sci. 2011, 2, 281-289.

30. Kamruzzaman, M.N.; Rehman, M.M. Shelflife of different types of dahi at room and refrigeration temperature. Pak. J. Nutr. 2002, 1, 234-237.

31. Isleten, M.; Karagul-Yuceer, Y. Effects of dried dairy ingredients on physical and sensory properties of nonfat yogurt. J. Dairy Sci. 2006, 89, 2865-2872. [CrossRef]

32. Guven, M.; Yasar, K.; Karaca, O.B.; Hayaloglu, A.A. The effect of inulin as a fat replacer on the quality of set-type low-fat yoghurt manufacture. Int. J. Dairy Technol. 2005, 58, 180-184. [CrossRef]

33. Hasan, M.; Huma, N.; Sameen, A.; Rafiq, S.; Gulzar, N. Use of meteroxylon sagu as a stabilizing agent in yoghurt. J. Food Chem. Nutr. 2014, 2, 19-26.

34. Dave, R.L.; Dave, J.M.; Sannabhadti, S.S. Micorbiological quality of some market and household dahi samples. Asian J. Dairy Res. 1992, 10, 111-114.

35. Ganesh, S. A Novel Yoghurt Product with Lactobacillus Acidophilus. Master's Thesis, Louisiana State University and Agricultural and Mechanical College, Baton Rouge, LA, USA, 2006.

(C) 2018 by the author. Licensee MDPI, Basel, Switzerland. This article is an open access article distributed under the terms and conditions of the Creative Commons Attribution (CC BY) license (http:/ / creativecommons.org/licenses/by/4.0/). 